\title{
Use of Household Survey Data as a Tool to Assess the Carbon Footprint of Rural Tourist Accommodation and Related Services in China: A Case Study of Mount Qingcheng
}

\author{
Jun Liu (D), Chu Lin, Li Huang *, Jianghuan Zhu, Lijun Wu and Yunyun Li \\ Tourism School, Sichuan University, 24 South Section 1 Ring Road No. 1, Chengdu 610065, Sichuan, China; \\ liujun_igsnrr@126.com (J.L.); levenalc@163.com (C.L.); alicezhu0325@163.com (J.Z.); \\ wulijun47@stu.scu.edu.cn (L.W.); arina_scdxlyy@126.com (Y.L.) \\ * Correspondence: Lily_2huang@163.com
}

Received: 28 July 2017; Accepted: 18 September 2017; Published: 21 September 2017

\begin{abstract}
The need to improve the accuracy of carbon emission measurements is a major issue which the tourism industry must resolve in order to reduce adverse impacts on climate change and the environment. This study established a detailed consumption list based on household survey data and calculated the carbon emissions of accommodation and services of the rural tourism industry of Mount Qingcheng using the input-output and lifecycle methods. Further, it analysed the key factors affecting carbon emissions. The results indicate that within the surveyed area, carbon emissions from accommodation and services amounted to $30.27 \mathrm{~kg} \mathrm{CO}_{2}$ / per person per day; these emissions were primarily from indirect sources, which accounted for $74.99 \%$ of the total emissions. Emissions from construction and production of durable goods accounted for $13.08 \%$ and $21.58 \%$ of the total emissions. The omission of these sources of carbon emissions was the primary reason for the carbon emission levels of the tourism industry being underestimated previously. For each additional 10,000 yuan in revenue, accommodation and related services of the rural tourism industry emit an additional $1412.08 \mathrm{~kg}$ of $\mathrm{CO}_{2}$. This is higher than the level of carbon emissions of the agriculture industry, but lower than those of the processing and manufacturing industries. Tourist consumption behaviours and types of tourism operations are important factors affecting carbon emissions. Effective emission reduction strategies include guiding tourist consumption behavioural changes, optimizing tourism operation portfolios, and extending the service life of constructions and durable goods.
\end{abstract}

Keywords: tourism industry; indirect carbon emissions; construction; durable goods

\section{Introduction}

Assessing the impact of climate change on the tourism industry and exploring how tourism plays an active role in responding to and mitigating climate change have become important areas of research related to the environmental impacts of tourism [1,2]. In particular, the scale of carbon emissions caused by the rapid development of the tourism industry has become a popular topic for research. A report by the United Nations World Tourism Organization (UNWTO) estimates that the tourism industry is responsible for $5 \%$ of global carbon emissions, and this figure can be as high as $14 \%$ for countries which primarily depend on the tourism industry for economic development [3]. In 2015, the number of individual Chinese domestic tourism trips reached four billion, while the number of tourists visiting from other countries (inbound tourists) reached 134 million, indicating a year-on-year growth rate of $10.5 \%$ and $4.1 \%$, respectively. The annual tourism revenue reached 4.13 trillion yuan [4]. As the importance of China's tourism industry grows, the issue of its carbon emissions becomes increasingly obvious. 
Given the growing contribution of the tourism industry to global climate change, the need for urgent mitigation of these effects has become critical [5]. Effective mitigation is dependent on accurate and complete assessments of the effects of various tourism factors and specific products on carbon emissions [6]. However, the responsibility of China's tourism industry with regard to carbon emissions and the potential for emission reduction is still unclear. To achieve China's overall objectives of carbon emission control and industrial emission reduction, the tourism industry must establish strategies in line with its own emissions status and potential. Overall, the accurate calculation of the tourism industry's carbon emissions forms the basis for achieving emission reductions. Furthermore, the scope of some existing studies on carbon emissions of the tourism industry is limited, because they primarily focus on the direct carbon emissions and neglect indirect carbon emissions [7]. Studies have reported that carbon emissions resulting from indirect energy account for about $50 \%$ of overall carbon emissions for residents, and this figure is projected to increase in the future [8]. To protect the normal operation of tourism activities, indirect consumption must be maintained between $25 \%$ and $65 \%$. For example, the indirect carbon emissions from New Zealand and Australia's tourism industries stand at $46 \%$ and $52 \%$ of the total carbon emissions of their tourism industries, respectively [6,7]. As a result, research on the indirect carbon emissions of tourism consumption can help provide a complete and objective understanding of the carbon emissions problems caused by energy consumption.

Currently, research concerning carbon emissions in the tourism industry often overlooks or underestimates carbon emissions due to tourism construction carried out by tourism operators to provide accommodation and related services for tourists [9,10]. Recently, a number of authors have explored the application of lifecycle assessment (LCA) in tourism, and there has been work on LCA in tourism around the world [11-13]. Traditional buildings in Nepal release about one-fourth of the greenhouse gas emissions released by semi-modern buildings, and less than one-fifth of the emissions of modern buildings [14]. The construction industry is a major source of carbon emissions, accounting for $36 \%$ of global carbon emissions [15]. These studies also overlook the carbon emissions from durable goods used by tourism operators, such as household electrical appliances and furniture. In 2007, emissions from Chinese household equipment, such as furniture and household electrical appliances, accounted for $5 \%$ of overall indirect carbon emissions [16]. For the operational use of all hotels in Greece, HVAC (heating, ventilation and air conditioning) systems are the most energy-intensive agents of environmental burden, followed by kitchens and production of hot water [17]. These two omissions from the measurement of indirect carbon emissions may have led to the underestimation of carbon emissions by the tourism industry. Establishing a list of commodity consumption by household survey is the best way to accurately measure the indirect carbon emissions of rural households in the scenic area of the back mountain of Mount Qingcheng, especially indirect carbon emissions of construction and durable goods.

Therefore, in this study a carbon emissions calculation framework which primarily addresses the problems of calculating indirect emissions implicit to tourism construction and durable consumer goods has been designed. It uses the back-mountain area of the Mount Qingcheng World Heritage Site as its object of research, due to its complete tourism ecosystem and the rapid development of tourism. We excluded the tourist transportation element from analysis, since we primarily focused on the carbon emissions of accommodation and services of the rural tourism operators. The study used household surveys to establish a detailed inventory of direct energy consumption in the rural tourism industry as well as a list of commodity consumption, including tourism construction and durable goods. These are used to calculate the carbon emissions of accommodation and services of the rural tourism industry of Mount Qingcheng, analyse the emission process and driving factors, and propose recommendations for reducing the carbon emissions of the rural tourism industry and promoting low carbon development. 


\section{Survey Area}

Mount Qingcheng is located in Sichuan Province, to the northwest of the Chengdu plain $\left(30^{\circ} 54^{\prime} \mathrm{N}, 103^{\circ} 35^{\prime} \mathrm{E}\right)$ (Figure 1). It has a perimeter of $120 \mathrm{~km}$ and a protected area which covers $1522 \mathrm{~km}^{2}$. Mount Qingcheng is both a natural and cultural World Heritage Site. It is one of the birthplaces of Chinese Taoism, and an important component of the natural habitat of Sichuan's giant pandas. In 2010, 612,000 people visited the Mount Qingcheng area, of which 308,700 were overnight tourists, representing $50.4 \%$ of the annual visitors [18]. Mount Qingcheng is divided into the front-mountain and back-mountain regions. The front mountain of Mount Qingcheng covers an area of about $15 \mathrm{~km}^{2}$ and is primarily a cultural tourism site. The back mountain has a trail which stretches more than $20 \mathrm{~km}$ and covers a total area of $100 \mathrm{~km}^{2}$. It is generally used for leisure activities during holidays. The front mountain is the main protected area of the World Heritage Site. The aboriginal populations have completely moved away from this area and now provide sightseeing activities for tourists. In the scenic area of the back mountain, the rural residents conduct activities to attract tourists. The region is China's earliest developing and most representative area, which has relied on its heritage site status to develop rural tourism. In the back-mountain area of Mount Qingcheng, nearly every household is engaged in tourism activities. These activities are primarily divided into three types: farmhouse-type, store-type, and stall-type operators (henceforth referred to as the farmhouse-type, store-type, and stall-type). Farmhouse-type operators primarily provide comprehensive services to tourists, such as food and beverages, accommodation, and entertainment. Store-type operators mainly include specialty product stores, souvenir stores, and small supermarkets. Stall-type operators sell snacks, fruits, and beverages, and they are characterized by having no fixed storefront, and being relatively small in scale. This study chose the back-mountain area of Mount Qingcheng as its primary survey area. We surveyed 150 rural households, with 556 family members, and 118 hired workers engaged in tourism operations. These rural households account for $38 \%$ of all households engaged in tourism operations in the surveyed area.

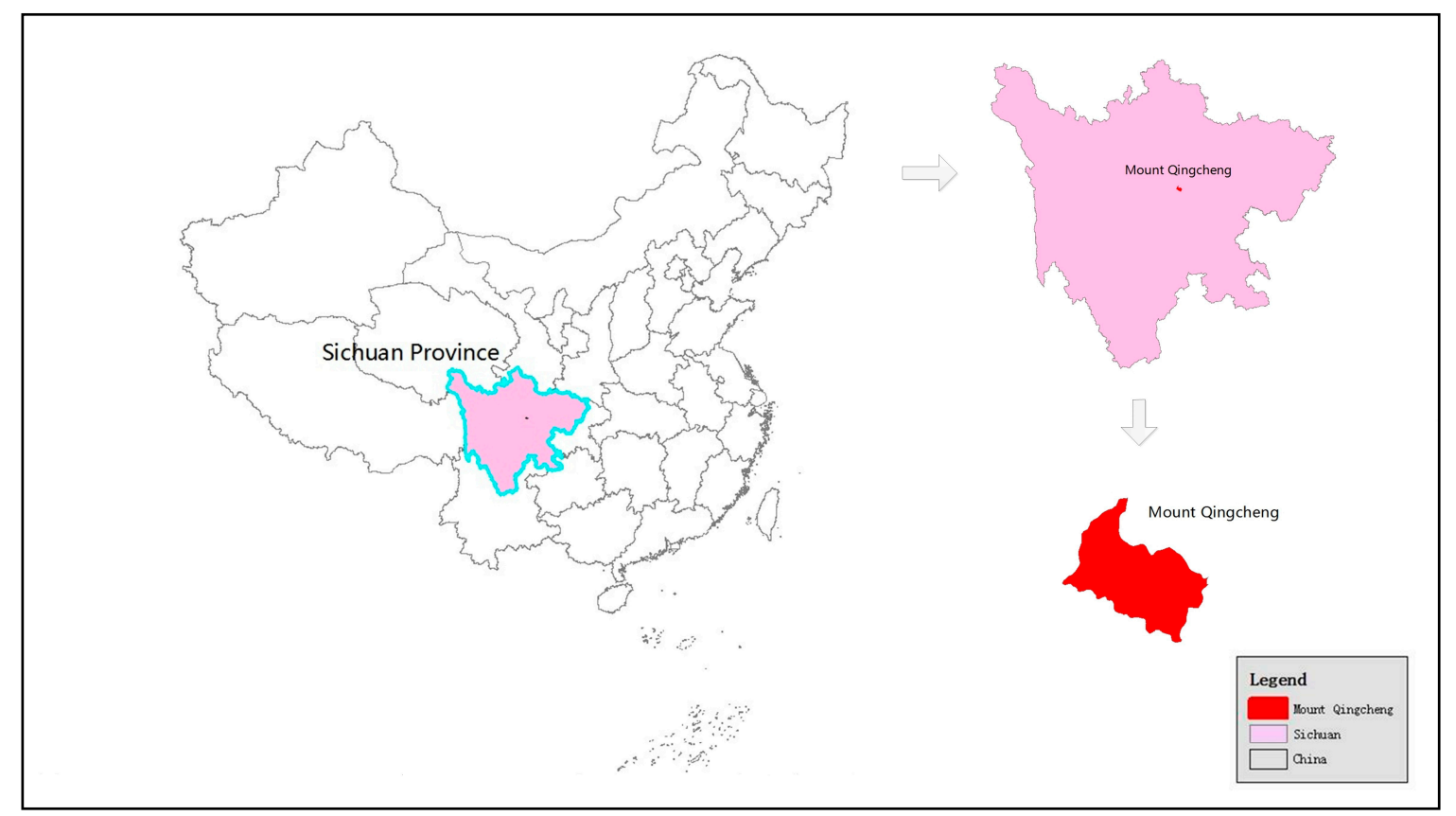

Figure 1. The location of Mount Qingcheng. 


\section{Materials and Methods}

\subsection{Data Sources}

The survey team conducted questionnaire surveys of rural households in the scenic area of the back-mountain area of Mount Qingcheng from July to September 2015. The main survey areas chosen are the most representative scenic points, with a high concentration of residences, including Tai'an Guzhen, Youyi Village, Baiyun Ancient Village, Hongyan New Village, Tonglinggou, and Feiquangou. The three types of tourism operators in the surveyed area are farmhouse-type, store-type, and stall-type. In the surveyed area, the primary type of operator is the farmhouse-type, comprising $75-85 \%$ of all tourism operators in the survey area. The second most common type is the stall-type operator, while the store-type operator was the least common. We chose long-term, relatively stable rural households to ensure the continuity and reliability of the data, and the subjects of the survey are the core family members of rural households. We stratified sample of rural households of different altitudes, and the survey is conducted using participatory interviews and the stratified random sampling questionnaire method. The average interview and questionnaire duration was longer than $1.5 \mathrm{~h}$. In total, 153 surveys were distributed and 150 were collected, yielding a valid questionnaire collection rate of $98.0 \%$. Thus, we confirm our final operator type ratios in our sample of 150 household tourism operators: $72 \%$ farmhouse-type, $20 \%$ stall-type, and $8 \%$ store-type operators.

The questionnaire content primarily includes four components. Firstly, there is the component of rural household basic conditions, which includes the number of family members and the industry in which they participate, as well as the duration and location of their participation, and living conditions (structure and number of floors in their residence). The second component is with respect to conditions relevant to tourism operation, which include the number of family members involved in the tourism industry, tourism operation projects, hours of work per year, number of customers per year, tourism income, and number of employees. Thirdly, there is a survey of direct household energy consumption, which includes the annual household consumption of electricity, natural gas, liquefied petroleum gas, petroleum, and firewood, measured by volume or value. Finally, there is a survey of indirect household energy consumption, which includes the following nine indirect energy consumption categories: food (including aquatic products, agricultural products, meat, drinks, etc.), textiles (including bed sheets, quilt cover, curtains, etc.), residences (including construction, furniture, kitchen utensils, etc.), household facilities, transportation and communication, entertainment and leisure (including books and magazines, chess table games, sports equipment, etc.), healthcare (including medicine, healthcare products, etc.), productive consumption (including agricultural machinery, agricultural seeds, plastic film, fertilizer, etc.), and other consumption and services (including handicrafts, wholesale and retail, etc.). While collecting data on direct and indirect energy consumption, there were some circumstances where the survey participants had difficulties or were unable to estimate their consumption. In these cases, we interviewed the participants on their daily or monthly average consumption levels during the peak season and off-season and the duration of the peak season and off-season, and then used this information to estimate the annual data. Besides, we also interviewed the rural household on some basic information, such as price levels, energy conservation awareness, etc.

This study has established a dataset from lists of tourism operations, household direct energy consumption, construction and durable goods consumption. We have used the level of income which tourism operators derive from the tourism industry as a proportion of the total household income to serve as our 'stripping coefficient', using this to 'strip' the tourism consumption from total household consumption. We removed the consumption of productive material from the list, which includes agricultural machinery, agricultural seeds, pesticides, etc., because farmers are engaged in agricultural production. We also removed the personal items that household members consume on a daily basis, which are irrelevant to tourism consumption. These included healthcare products, clothing, shoes, and hats, etc. In this way, we derive the supply-side consumption data of the tourism industry. Additional data required for calculations were derived from the following sources: 'The IPCC 
(Intergovernmental Panel on Climate Change) Guidelines for National Greenhouse Gas Inventories'; the '2014 Baseline Emissions Factors for Regional Power Grids in China' published by the National Reform and Development Council's Climate Change Department; the 2012 China Energy Statistical Yearbook [19]; the '2012 Chinese Input-Output Tables'; and the 'Enterprise Income Tax Law and Implementation Rules of the People's Republic of China'.

\subsection{Calculation of Carbon Emissions from Rural Tourism}

- Direct carbon emission calculations

Direct carbon emissions include carbon emissions from direct energy consumption, including the four components of fossil energy sources (coal, natural gas, liquefied petroleum gas, and gasoline), electricity, and biomass energy.

$$
\begin{gathered}
C^{\text {direct }}=C^{f e}+C^{e l e c}+C^{b i o}, \\
C^{f e}=\sum_{i} e_{i} \times k_{i}, \\
C^{\text {elec }}=e_{\text {elec }} \times E F_{G R I D},
\end{gathered}
$$

$C^{f e}$ denotes carbon emissions generated from fossil energy sources, $k_{i}$ denotes the $\mathrm{CO}_{2}$ emissions coefficient for the $i$ th type of fossil energy source, and $e_{i}$ denotes the volume consumed of the $i$ th type of petroleum energy source. $C^{\text {elec }}$ denotes carbon emissions from electricity consumption, $e^{\text {elec }}$ denotes consumption of electricity in $\mathrm{kWh}$, and enotes the $\mathrm{CO}_{2}$ emissions coefficient from electricity consumption. We used the weightings from the $E F_{G R I D} 2014$ Chinese regional power grid 'electricity marginal emissions coefficient' and 'capacity marginal emissions coefficient' [20]. We calculated the electricity emissions coefficient for the back-mountain region of Mount Qingcheng, which was equal to $0.72305 \mathrm{~kg} \mathrm{CO}_{2} \cdot \mathrm{kW}^{-1} \cdot \mathrm{h}^{-1}$.

The use of biomass energy has local environmental effects. Based on the status of China and the surveyed area, we also included biomass energy in our calculations of direct carbon emissions. Biomass energy for China's rural areas, including firewood, straw, and biogas, is calculated as follows [21]:

$$
\begin{gathered}
C^{b i o}=C_{B M}+C_{B G}, \\
C_{B M}=\sum e_{B M} \times c_{B M} \times o_{B M} \times \frac{44}{12}, \\
C_{B G}=e_{B G} \times r_{B G} \times c_{B G} \times \frac{44}{12},
\end{gathered}
$$

$C^{b i o}$ denotes carbon emissions from biomass energy, $C_{B M}$ denotes carbon emissions from firewood and straw, $e_{B M}$ denotes the consumed volume of firewood or straw, $c_{B M}$ denotes carbon content, and $o_{B M}$ denotes the oxidation rate. $C_{B G}$ denotes carbon emissions from biogas, $e_{B G}$ denotes the consumed volume of biogas, $r_{B G}$ denotes the calorific value of biogas, $c_{B G}$ denotes the carbon content of biogas, and 44/12 represents the ratio of molecular weights between $\mathrm{CO}_{2}$ and carbon atoms.

- Calculation of indirect carbon emissions

Indirect carbon emissions refer to carbon emissions resulting indirectly from the production, processing, transportation, use, and disposal of non-energy products and services consumed in daily life, such as food, textile, housing, and travel. Indirect carbon emissions are calculated using the following equation:

$$
C^{\text {indirect }}=C^{\text {con }}+C^{i o},
$$


where $C^{\text {indirect }}$ denotes the total amount of indirect carbon emissions, $C^{c o n}$ denotes carbon emissions from the materialization stage of construction, and $C^{i o}$ denotes indirect carbon emissions from tourists' consumption other than construction.

- Calculation of indirect carbon emissions from tourism construction

Currently, the most common method of calculating construction emissions is based on the construction lifecycle (Figure 2). According to the input-output method, calculation of the carbon emissions of construction includes only the construction and installation of decorations and building preparation stages. However, the materialization stage of the construction lifecycle, which consists of raw material retrieval, material production and component manufacturing, and construction and installation processes, yields a more complete calculation of indirect carbon emissions from construction (Figure 2).

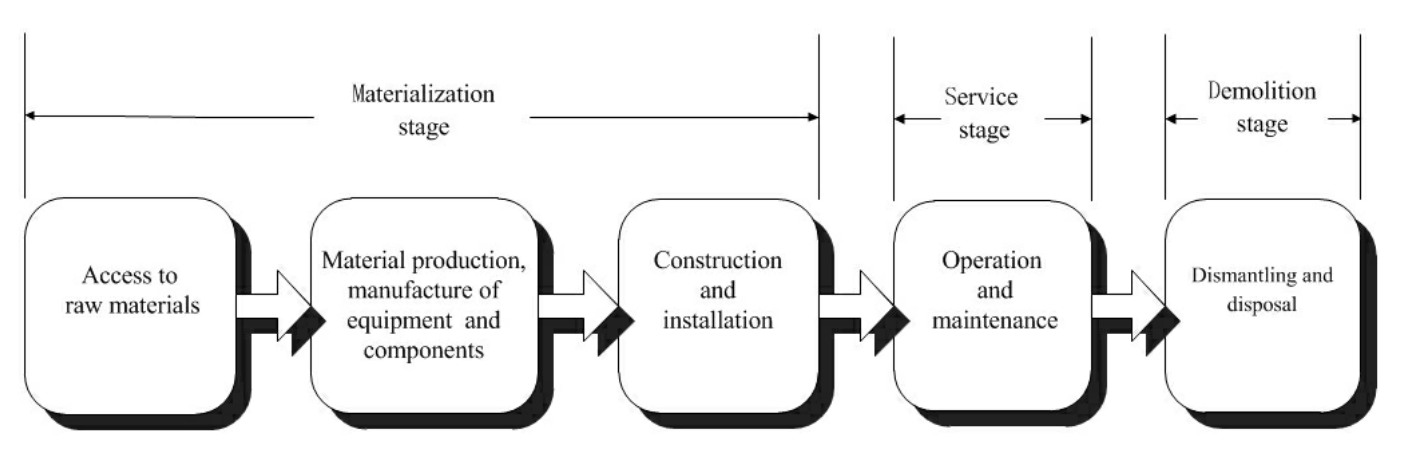

Figure 2. Construction life cycle.

Thus, with regard to carbon emissions from tourism construction, this study has referred to the calculation method used by $\mathrm{Qu}$, which gives the carbon emissions from the materialization stage of tourism construction to calculate indirect carbon emissions [22]. This calculation method is given by the equation below:

$$
C^{c o n}=\sum A_{m} \times d_{m} \times \frac{1}{20}
$$

where $C^{c o n}$ denotes the fixed carbon emissions of construction, while $m$ denotes the four structural types of construction in the back-mountain area of Mount Qingcheng, such as wood structures, brick and wood structures, brick and concrete structures, and reinforced concrete structures. The carbon emissions factors for these structures are $63.296 \mathrm{~kg} \mathrm{CO} / \mathrm{m}^{2}, 220.489 \mathrm{~kg} \mathrm{CO} / \mathrm{m}^{2}, 274.615 \mathrm{~kg} \mathrm{CO} / \mathrm{m}^{2}$, and $308.444 \mathrm{~kg} \mathrm{CO} 2 / \mathrm{m}^{2}$, respectively. $A_{m}$ denotes the total area covered by the $m$ th type of construction, while $d_{m}$ represents the carbon emissions factor for the $m$ th type of construction. The average life expectancy of rural housing is 20 years [23].

- Calculation of indirect carbon emissions from other forms of consumption in tourism

This study classifies the indirect energy consumption of rural households in Mount Qingcheng into seven categories: foods, textiles, residence, household facilities, transportation and communication, entertainment and leisure, and other consumption and services. The energy demands of these consumption categories can be traced back to the industrial energy consumption from the production of related products or the provision of services. For the calculation, we combined the 47 sectors from the 2012 China Energy Statistical Yearbook [19] and the 139 sectors from the '2012 Input-Output Tables' to form nine sectors. One method for the calculation of carbon emissions due to consumption by tourists is the consumer lifestyle method. This method is more effective in combining consumption lists for the calculation of carbon emissions from each item of consumption. Considering the intertwined relationship of energy consumption by each sector of the economy, this study refers 
to the Wang method of calculating residents' indirect carbon emissions from consumption, adding environmental input-output lifecycle analysis and the consumer lifestyle method, thus giving the following equations for calculating the indirect carbon emissions of tourism [17]:

$$
\begin{gathered}
C^{i o}=F^{\prime} Y=F(I-A)^{-1} Y, \\
f_{j}=C_{j} / X_{j},
\end{gathered}
$$

where $C^{i o}$ denotes indirect carbon emissions from tourists' consumption other than construction, $j$ denotes the post-merge sector code, $A$ denotes the direct consumption coefficient matrix. $(I-A)^{-1}$ is the Leontief inverse matrix, $Y$ denotes the consumption expenditure of each sector, which must be converted into a constant 2012 price according to the price index, $F$ is the carbon emission intensity of the sector corresponding to the nine consumption types, $f_{j}$ is the carbon emission intensity of the $j$ th sector, $C_{j}$ denotes the total carbon emissions from the $j$ th sector, and $X_{j}$ denotes the added value of the $j$ th sector. Considering the energy structures of the nine sectors, based on the energy balance table of the nine merged sectors and the 'Industrial Sub-sector Terminal Energy Consumption', we have chosen 19 kinds of energy products, such as raw coal, washed coal, and petroleum energy products to calculate the carbon emissions of the nine sectors, using the following equation:

$$
C_{j}=\sum_{q} e_{q} \times k_{q}+Q_{j}+H_{j}
$$

Here, $q$ is the energy type of sector $j, C_{j}$ is the carbon emissions of sector $j, e_{q}$ is the consumption amount of the $q$ th energy source, $k_{q}$ is the $\mathrm{CO}_{2}$ emissions coefficient of energy type $q, Q_{j}$ is the electricity consumption of sector $j$, and $H_{j}$ is the heat energy consumption of sector $j$, calculated in the calorific capacity of raw coal.

- Rural tourism carbon emission calculations

The carbon emissions by the surveyed area's tourism industry are equal to the direct emissions and the indirect emissions of rural tourism. For this, the following equation is used:

$$
\begin{gathered}
C_{T}^{\text {tourism }}=C^{\text {direct }}+C^{\text {indirect }}, \\
C_{T}^{\text {t-average }}=C_{T}^{\text {tourism }} / p,
\end{gathered}
$$

$C_{T}^{\text {tourism }}$ denotes the carbon emissions of rural tourism, $p$ is the corresponding number of trips, and $C_{T}^{t-\text { average }}$ denotes the average carbon emissions per person.

All the required parameters are summarized as follows (Table 1):

Table 1. Main parameters.

\begin{tabular}{cclc}
\hline Formula & Parameter & \multicolumn{1}{c}{ Description } & Unit \\
\hline$(2)$ & $k_{i}$ & $\begin{array}{l}\text { the } \mathrm{CO}_{2} \text { emissions coefficient for the } i \text { th type of } \\
\text { fossil energy source }\end{array}$ & $\begin{array}{c}\mathrm{kg} \mathrm{CO}_{2} \cdot \mathrm{kg}^{-1} \\
\mathrm{or} \mathrm{kg} \mathrm{CO}_{2} \cdot \mathrm{m}^{-3}\end{array}$ \\
\hline$(2)$ & $e_{i}$ & $\begin{array}{l}\text { the consumed volume of the } i \text { th type of fossil } \\
\text { energy source }\end{array}$ & $\mathrm{Kg} \mathrm{or} \mathrm{m}$ \\
\hline$(3)$ & $e_{\text {elec }}$ & represents consumption of electricity in $\mathrm{kWh}$ & $\mathrm{kWh}$ \\
\hline$(3)$ & $E F_{G R I L}$ & $\begin{array}{l}\text { the } \mathrm{CO}_{2} \text { emissions coefficient from electricity } \\
\text { consumption }\end{array}$ & $\mathrm{kg} \mathrm{CO}_{2} \cdot \mathrm{kW}-1 \cdot \mathrm{h}-1$ \\
\hline$(5)$ & $e_{B M}$ & the consumed volume of firewood or straw & $\mathrm{kg}$ \\
\hline
\end{tabular}


Table 1. Cont.

\begin{tabular}{cccc}
\hline Formula & Parameter & \multicolumn{1}{c}{ Description } & Unit \\
\hline$(5)$ & $c_{B M}$ & carbon content & $\%$ \\
\hline$(5)$ & $o_{B M}$ & the oxidation rate & $\mathrm{m}^{3}$ \\
\hline$(6)$ & $e_{B G}$ & the consumed volume of biogas & $\mathrm{J} / \mathrm{kg}$ \\
\hline$(6)$ & $r_{B G}$ & the calorific value of biogas & $\mathrm{t} / \mathrm{TJ}$ \\
\hline$(6)$ & $c_{B G}$ & the carbon content of biogas & $\mathrm{m}^{2}$ \\
\hline$(8)$ & $A_{m}$ & $\begin{array}{l}\text { the total area covered by the } m \text { th type of } \\
\text { construction }\end{array}$ & $\mathrm{kg} \mathrm{CO} \cdot \mathrm{m}^{-2}$ \\
\hline$(9)$ & $d_{m}$ & $\begin{array}{l}\text { the carbon emissions factor for the } m \text { th type of } \\
\text { construction }\end{array}$ & the direct consumption coefficient matrix \\
\hline$(9)$ & $(I-A)^{-1}$ & the Leontief inverse matrix & 10,000 yuan \\
\hline$(9)$ & $Y$ & $\begin{array}{l}\text { the consumption expenditure for each sector, } \\
\text { which must be converted into a constant } 2012\end{array}$ \\
\hline$(10)$ & $f_{i}$ & $\begin{array}{l}\text { price according to the price index } \\
\text { the carbon emissions intensity of the } j \text { th sector }\end{array}$ & $\begin{array}{c}\mathrm{kg} \mathrm{CO}_{2} / \\
10,000 \text { yuan }\end{array}$ \\
\hline$(10)$ & $C_{j}$ & the total carbon emissions from the $j$ th sector & $\mathrm{kg} \mathrm{CO}_{2}$ \\
\hline
\end{tabular}

Note: $\mathrm{kg} \mathrm{CO}_{2} / 10,000$ yuan is the unit used to measure carbon emissions intensity in China. Carbon emissions intensity refers to the amount of $\mathrm{CO}_{2}$ emissions increase brought on by a one-unit growth in GDP (Gross Domestic Product).

\section{Results}

\subsection{Direct Carbon Emissions of the Tourism Industry}

The direct carbon emissions of the accommodation and services per person per day in the surveyed area were $7.57 \mathrm{~kg}$ of $\mathrm{CO}_{2}$. Firewood and electricity were the primary sources of carbon emissions from the accommodation and services of the rural tourism industry. Specifically, the $\mathrm{CO}_{2}$ emissions from electricity were the highest at $2.79 \mathrm{~kg} \mathrm{CO}$, accounting for $37 \%$ of the total. The emissions from firewood were $2.40 \mathrm{~kg} \mathrm{CO}_{2}$, accounting for $32 \%$ of the total. Emissions from gasoline were $1 \mathrm{~kg} \mathrm{CO}$, accounting for $13 \%$ of the total. $\mathrm{CO}_{2}$ emissions from natural gas were $0.92 \mathrm{~kg}$, which accounts for $12 \%$ of the total. Emissions from liquefied petroleum gas were $0.33 \mathrm{~kg}$, accounting for $4 \%$ of the total. Charcoal emitted $0.02 \mathrm{~kg}$ of $\mathrm{CO}_{2}$, accounting for $0.2 \%$ of the total. Finally, straw and biogas generated the least emissions, with $0.0002 \mathrm{~kg}$ of $\mathrm{CO}_{2}$, accounting for $0.03 \%$ of total emissions (Table 2 ).

Table 2. The direct carbon emissions per person per day of the surveyed area. LPG: liquefied petroleum gas.

\begin{tabular}{ccc}
\hline Consumption Type & Direct Carbon Emissions (kg) & Proportion \\
\hline Electricity & 2.79 & $36.88 \%$ \\
Firewood & 2.40 & $31.68 \%$ \\
Gasoline & 1.00 & $13.15 \%$ \\
Natural gas & 0.92 & $12.21 \%$ \\
LPG (Liquefied Petroleum Gas) & 0.33 & $4.35 \%$ \\
Honeycomb coal & 0.11 & $1.46 \%$ \\
Charcoal & 0.02 & $0.20 \%$ \\
Straw & 0.002 & $0.03 \%$ \\
Biogas & 0.002 & $0.03 \%$ \\
Total & 7.57 & $100 \%$ \\
\hline
\end{tabular}


Although local governments have already actively promoted the use of relatively clean energy sources like natural gas and liquefied petroleum gas, our survey found that energy sources such as firewood remain important sources of energy in tourist areas. As a result, reducing or restricting the use of non-clean energy sources is an important method for promoting clean production and reduced tourism emissions in the heritage site.

\subsection{Indirect Carbon Emissions from the Tourism Industry}

\subsubsection{The Intensity of Indirect Carbon Emissions}

The input-output method is used to calculate the indirect carbon emissions intensity of different consumption categories. The highest indirect carbon emission intensity is for residences (construction, furniture, etc.), equivalent to $9421.61 \mathrm{~kg} \mathrm{CO}_{2} / 10,000$ yuan. The indirect carbon emission intensity of the textiles and food industries was relatively low, at $5593.88 \mathrm{~kg} \mathrm{CO}_{2} / 10,000$ yuan and $3901.42 \mathrm{~kg} \mathrm{CO} 2 / 10,000$ yuan, respectively. The indirect carbon emission intensity of other consumption and services (handicrafts, wholesale and retail, etc.) was the lowest, at just $3588.45 \mathrm{~kg} \mathrm{CO}_{2} / 10,000$ yuan (Table 3$)$.

Table 3. The intensity of indirect carbon emissions of China in 2012.

\begin{tabular}{cc}
\hline Consumption Type & The Intensity of Indirect Carbon Emissions (kg/10 $\mathbf{~ Y u a n})^{\mathbf{4}}$ \\
\hline Residence & 9421.61 \\
Household facilities & 7524.21 \\
Transportation and communication & 7150.62 \\
Entertainment and leisure & 6594.48 \\
Textile & 5593.88 \\
Food & 3901.42 \\
Other consumption and services & 3588.45 \\
\hline
\end{tabular}

\subsubsection{The Indirect Carbon Emissions}

The per person per day indirect carbon emissions of the surveyed area were $22.70 \mathrm{~kg} \mathrm{CO}_{2}$, which is about 3.00 times the amount of direct carbon emissions. Food was the primary source of indirect carbon emissions by the tourism industry. Carbon emissions from food were equal to $9.89 \mathrm{~kg} \mathrm{CO}_{2}$ per person, accounting for $43.59 \%$ of the total indirect emissions. Carbon emissions from residences were second only to emissions from food, producing $5.61 \mathrm{~kg} \mathrm{CO}_{2}$ per person and accounting for $24.70 \%$ of the indirect emissions. From other consumption and services, there were $2.31 \mathrm{~kg} \mathrm{CO}_{2}$ of emissions, accounting for $10.17 \%$ of the indirect emissions. With respect to transportation and communication, emissions were $1.96 \mathrm{~kg}$, accounting for $8.62 \%$ of the indirect emissions. Entertainment and leisure yielded a value $1.75 \mathrm{~kg} \mathrm{CO}_{2}$, accounting for $7.72 \%$ of the indirect emissions. Further, there were $0.87 \mathrm{~kg}$ of emissions from textiles, accounting for $3.82 \%$ of the indirect emissions. Finally, household equipment emissions were $0.31 \mathrm{~kg} \mathrm{CO}_{2}$, accounting for $1.38 \%$ of the total indirect emissions (Table 4 ).

Table 4. The per person per day indirect carbon emissions of the surveyed area.

\begin{tabular}{ccc}
\hline Consumption Type & Indirect Carbon Emissions (kg) & Proportion \\
\hline Food & 9.89 & $43.59 \%$ \\
Residence & 5.61 & $24.70 \%$ \\
Other consumption and services & 2.31 & $10.17 \%$ \\
Transportation and communication & 1.96 & $8.62 \%$ \\
Entertainment and leisure & 1.75 & $7.72 \%$ \\
Textiles & 0.87 & $3.82 \%$ \\
Household facilities & 0.31 & $1.38 \%$ \\
Total & 22.70 & $100 \%$ \\
\hline
\end{tabular}




\subsection{Overall Carbon Emissions of the Tourism Industry}

In total, tourism in the back-mountain area of Mount Qingcheng results in emissions of $30.27 \mathrm{~kg}$ of $\mathrm{CO}_{2}$ per person per day, of which $74.99 \%$ of the emissions are indirect. Thus, indirect emissions represent the primary source of carbon emissions in the tourism industry. The amount of $\mathrm{CO}_{2}$ emitted by each tourist in each visit to the surveyed area is 1.33 times the Chinese tourism industry's national average (22.7 $\mathrm{kg} \mathrm{CO}_{2}$ per person). For each additional 10,000 yuan in revenue generated by the tourism industry in the surveyed area, $1412.08 \mathrm{~kg}$ of additional $\mathrm{CO}_{2}$ is produced. This is 3.92 times the national average of China's tourism industry ( $360 \mathrm{~kg} \mathrm{CO}_{2} / 10,000$ yuan), which is a higher value than for its agricultural industry (1070 $\mathrm{kg} \mathrm{CO}_{2} / 10,000$ yuan), but lower than for its processing and manufacturing industries (Table 5). We can observe that the carbon emission level of the tourism industry in the surveyed area is relatively high, and the benefit of emitting an additional $1 \mathrm{~kg}$ of $\mathrm{CO}_{2}$ is not high, although the industry has a relatively low-carbon sector when compared with other industries (Table 6).

Table 5. Tourism carbon emission index [24-26].

\begin{tabular}{|c|c|c|c|c|c|}
\hline & $\begin{array}{l}\text { Totals } \\
\text { (Mt) }\end{array}$ & $\begin{array}{l}\text { Tourist Trips } \\
\text { (Million) }\end{array}$ & $\begin{array}{c}\text { Tourism Revenue } \\
\text { (Billion) }\end{array}$ & $\begin{array}{c}\text { Per Person } \\
\mathrm{CO}_{2}(\mathrm{~kg} \mathrm{CO})\end{array}$ & $\begin{array}{c}\text { Per 10,000 Yuan } \\
\left.\mathrm{CO}_{2}(\mathrm{~kg} \mathrm{CO})_{2}\right)\end{array}$ \\
\hline Direct in China (2010) & 17.7 & 2240 & 1570 & 7.89 & 113 \\
\hline China (2008) & 41.7 & 1840 & 1160 & 22.7 & 360 \\
\hline $\begin{array}{c}\text { Study area } \\
\text { (number of samples: 150) }\end{array}$ & 0.0085 & 0.282 & 0.0604 & 30.27 & 1412.08 \\
\hline
\end{tabular}

Note: In order to maintain statistical consistency, carbon emissions caused by external transportation are excluded. Numbers of Chinese tourists and tourism revenues were retrieved from The Chinese Statistical Yearbook [19].

Table 6. Carbon intensity of Chinese industries in 2007 [27].

\begin{tabular}{cc}
\hline Industry & $\begin{array}{c}\text { Industries Carbon Intensity } \\
\text { (kg CO } \mathbf{2} / \mathbf{1 0}, \mathbf{0 0 0} \text { Yuan) }\end{array}$ \\
\hline Agriculture, Forestry, Animal Husbandry and Fishery & 1070 \\
\hline Mining and Washing of Coal & 3050 \\
\hline Manufacture of Food and Processing of Tobacco & 1350 \\
\hline Processing of Timber and Manufacture of Furniture & 2060 \\
\hline $\begin{array}{c}\text { Manufacture of Paper, Printing, Articles For Culture, } \\
\text { Education and Sport Activities }\end{array}$ & 1820 \\
\hline Manufacture of Non-metallic Mineral Products & 2180 \\
\hline Manufacture of Metal Products & 3860 \\
\hline Manufacture of General Purpose Machinery and Special \\
Purpose Machinery & 3350 \\
\hline Manufacture of Transport Equipment & 2710 \\
\hline Manufacture of Electrical Machinery and Equipment & 2430 \\
\hline Production and Supply of Electric Power and Heat Power & 3030 \\
\hline Construction & 2700 \\
\hline
\end{tabular}

\subsection{Carbon Emissions of Different Tourism Operation Types}

For one trip, carbon emissions from the farmhouse-type are the highest $(25.21 \mathrm{~kg})$, followed by the stall-type $(2.93 \mathrm{~kg})$, and finally the store-type operations $(2.13 \mathrm{~kg})$, which emit the least amount of 
carbon dioxide. For each 10,000 yuan in revenue, carbon emissions of the farmhouse-type operations are the lowest $(1278.14 \mathrm{~kg})$, followed by the store-type $(2049.84 \mathrm{~kg})$, and finally the stall-type operations $(4356.74 \mathrm{~kg})$, as indicated in Table 7.

Table 7. Carbon emissions index among rural inns, retailers, and tourism workers.

\begin{tabular}{ccc}
\hline Class & $\begin{array}{c}\text { Per Person Carbon Emissions } \\
(\mathbf{k g ~ C O} \mathbf{~})\end{array}$ & $\begin{array}{c}\text { Per 10,000 Yuan Carbon Emissions } \\
\mathbf{( k g ~ C O}_{\mathbf{2}} \mathbf{)}\end{array}$ \\
\hline Farmhouse-type & 25.21 & 1278.14 \\
Store-type & 2.13 & 2049.84 \\
Stall-type & 2.93 & 4356.74 \\
\hline
\end{tabular}

The primary sources of direct carbon emissions for these three types of operations are electricity and firewood, accounting for $69 \%, 74 \%$, and $66 \%$ of the total direct carbon emissions, respectively (Figure 3). For the farmhouse-type, the key sources of indirect carbon emissions are food $(43.87 \%)$, residences $(28.42 \%)$ and transportation and communication $(8.70 \%)$. For the store-type, the key sources of indirect carbon emissions are other consumption and services $(47.68 \%)$ and food $(26.41 \%)$, while for the stall-type, the key sources of indirect carbon emissions are food (55.65\%), and other consumption and services (22.31\%) (Figure 4). This is related to the tourism products and services provided by each operator type, and is consistent with their respective characteristics.

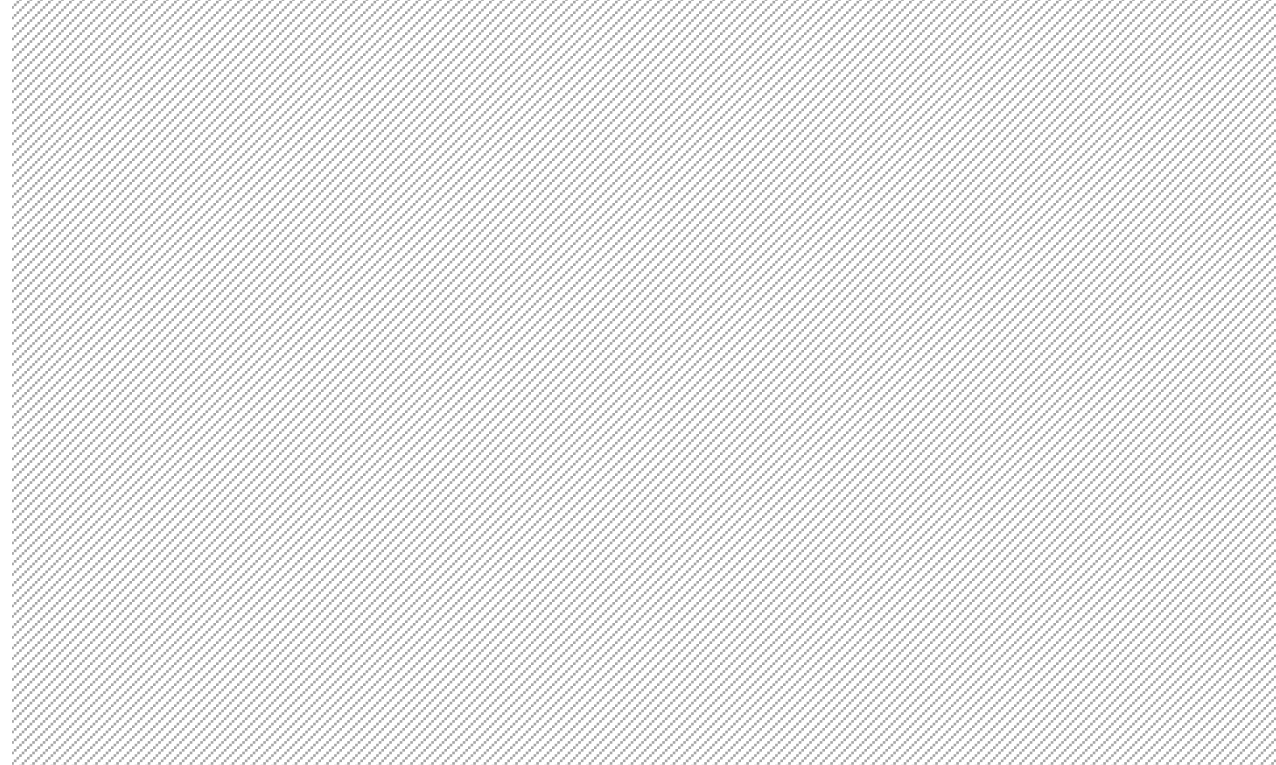

Figure 3. Structure of per trip direct carbon emissions of different types of tourism operations. A: electricity; B: firewood; C: natural gas, D: gasoline, E: liquefied petroleum gas (LPG); F: charcoal, G: straw; H: honeycomb coal; I: biogas.

\subsection{Rural Tourism Industry's Process of Carbon Emissions and Its Influencing Factors}

\subsubsection{Consumption Behaviours of Tourists}

The consumption behaviours of tourists affect the total amount of carbon emissions. To satisfy the increasingly varied demands of tourists, raise the comfort level of the accommodation, and increase competitiveness, local rural residents are renovating old constructions, decorating room interiors, purchasing new household appliances, and replacing bedding products much more frequently and in much greater quantities. This has caused the carbon emissions resulting from construction and durable goods in the surveyed area to increase. Considering the acquisition, processing, transportation, 
and installation of raw materials, the carbon emissions resulting from the materialization stage of construction amounted to $3.96 \mathrm{~kg}$ per person, or $13.08 \%$ of the total tourism industry's carbon emissions, while durable goods amounted to $6.53 \mathrm{~kg}$ per person, or $21.58 \%$ of the total emissions. The combined carbon emissions from construction and durable goods represented $34.66 \%$ of the total emissions, which is over one-third of the total carbon emissions emitted in the surveyed area. La rou, a traditional Chinese delicacy, is also a local specialty meat product of the surveyed area. Firewood-smoked pork is a favourite of tourists in the area and is in high demand. As a result, the demand for pork has increased, along with the number of pig farmers. The carbon emissions from la rou pork consumed per person amounts to $1.68 \mathrm{~kg}$ of $\mathrm{CO}_{2}$ emissions, which is $5.55 \%$ of the total emissions and $5.93 \%$ of the emissions from firewood consumption. Additionally, $1.98 \%$ of firewood consumption is represented by tourist barbecues, while $6.98 \%$ of carbon emissions are derived from ingredients used for barbecues (Figure 5).

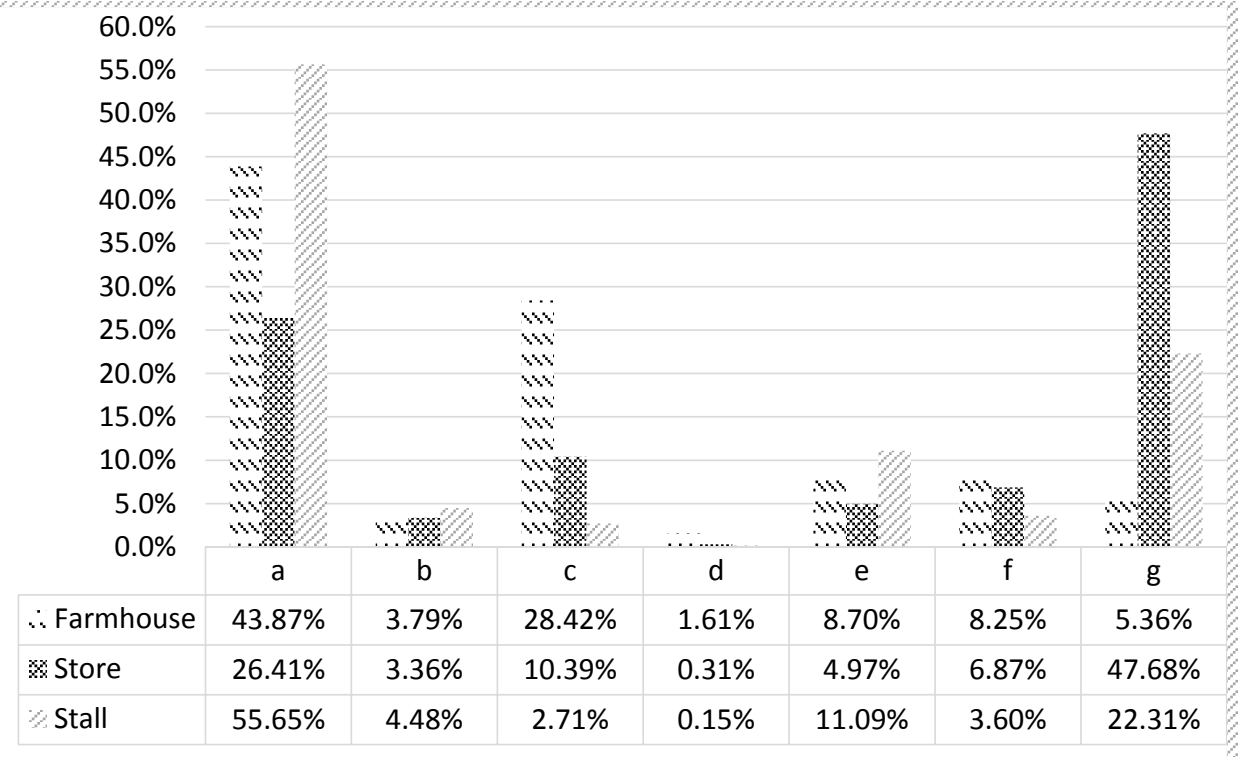

Figure 4. Structure of per trip indirect carbon emissions of different types of tourism operations. a: food; b: textile; c: residence; d: household facilities; e: transportation and communication; f: entertainment and leisure; g: other consumption and services.

\subsubsection{Types of Tourism Operation}

Different types of tourism operations represent different contributions to the structure of carbon emissions. The farmhouse-type operations primarily provide food and drink, housing, entertainment, and transportation for short trips within scenic areas. Food and drink services and housing services are the primary sources of carbon emissions, representing $27.38 \%$ and $17.74 \%$ of the total emissions, respectively. The store-type operations include groceries, souvenir stores, and specialty stores, and primarily provide souvenirs and specialty products. The sale of food and other goods represent $4.30 \%$ of the total emissions. The stall-type operations primarily provide water, smoked pork ribs, and sausages for hikers on the mountain. This provision of food for hikers leads to $3.77 \%$ of the total carbon emissions. Carbon emissions resulting from the sale of other products represent $1.51 \%$ of the total emissions. Comparing per-person carbon emissions levels, we found that emissions from the farmhouse-type operations were greater than emissions from the other types, and the store-type contributed the least. When comparing the emissions levels per 10,000 yuan in revenue, we found that the farmhouse-type had the lowest emissions, while the store-type produced a little more. It is clear that the farmhouse- and store-type operations benefit from economies of scale, and that they derive greater benefit from the emission of $1 \mathrm{~kg}$ of $\mathrm{CO}_{2}$. 


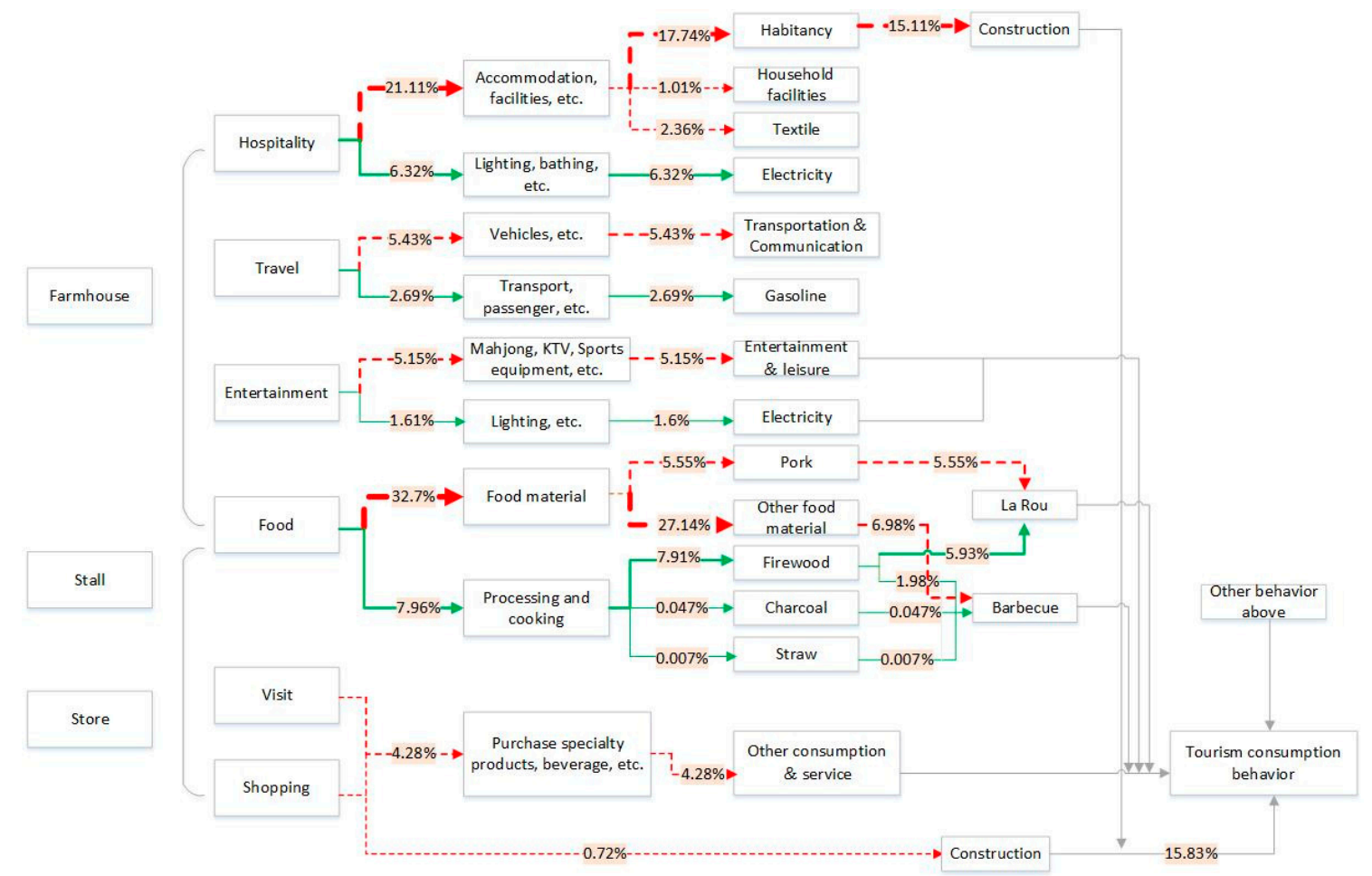

Figure 5. Main processes of rural tourism carbon emissions. The red line segments represent indirect carbon emissions and the green line segments represent direct carbon emissions. The thickness of the line segments indicates the proportion of carbon emissions contributed by the respective source in the tourism industry.

\section{Discussion}

Tourism operators can effectively reduce carbon emissions through food product management. Gössling notes that one can engage in climate sustainable food management through the three elements of procurement, preparation, and presentation, and believes that these measures can reduce greenhouse gasses by $50-80 \%$ [28]. With regard to food procurement, vegetables grown in heated greenhouses emit more greenhouse gasses than ordinary vegetables; for example, cucumbers grown in heated greenhouses produce 180 times more carbon emissions per kcal than tomatoes or onions grown in ordinary soil $[29,30]$. Thus, when making food purchases, we recommend avoiding vegetables grown in heated greenhouses as much as possible. There are also large amounts of GHG emissions due to meat consumption, varying significantly among different types of meat. From greatest to least, common meat emissions can be ranked as follows: beef $\left(10 \mathrm{~kg} \mathrm{CO}_{2}-\mathrm{e}\right)$, mutton $\left(8 \mathrm{~kg} \mathrm{CO}_{2}-\mathrm{e}\right)$, chicken (7 kg CO $2-e)$, and pork (2 $\left.\mathrm{kg} \mathrm{CO}_{2}-\mathrm{e}\right)$ [31,32]. Guiding tourists to change their food consumption habits is an important step in reducing carbon emissions. In this surveyed area, meat consumption primarily consists of pork, chicken, and mutton, with the proportions of pork and chicken consumption being the highest. A specialty meat product of the back-mountain area of Mount Qingcheng, la rou, is well-liked by many tourists. The carbon emissions used in the production of la rou account $11.1 \%$ of the total carbon emissions from the lodgings and services in the back-mountain area of Mount Qingcheng. This paper has measured and calculated the per-person per person daily carbon emissions of visitors to the back-mountain area of Mount Qingcheng, which is $30.27 \mathrm{~kg}$. The daily direct emissions per person are $7.57 \mathrm{~kg}$, while the daily indirect emissions per person are $22.70 \mathrm{~kg}$. Kuo and Chen (2009) used lifecycle assessment (LCA) and found that daily direct carbon emissions per person are $34 \mathrm{~kg}$ [33]. This value is much higher than the average per-person carbon emissions calculated by this study for the back-mountain area of Mount Qingcheng. This is primarily because Penghu Island is a tourism island, and carbon emissions from tourism transportation account for $67 \%$ of the 
total emissions. After eliminating tourism transportation emissions, the per-trip daily emissions from tourists in Penghu Island are $11 \mathrm{~kg}$, only slightly higher than the figures obtained in this study. Sun and Pratt (2014) used an environmentally extended input-output model to calculate the daily per-person amount of greenhouse gasses emitted by mainland Chinese tourists in the Taiwan tourism market (excluding air travel). They estimated the $\mathrm{CO}_{2}$ emissions at $52 \mathrm{~kg}$ by assuming a $\mathrm{CO}_{2}$ ratio of $55 \%$ in greenhouse gases according to the Kyoto Protocol. Further, direct $\mathrm{CO}_{2}$ emissions represented $26 \mathrm{~kg}$ of this amount, while indirect emissions accounted for $25 \mathrm{~kg}$ [34]. In these figures, direct carbon emissions are 3.4 times the amount calculated in this study, which may be a result of other external transportation factors other than air travel, such as cars and trains. Comparing indirect carbon emissions levels, the figure calculated by Sun and Pratt is slightly more than the figure calculated by this study.

When assessing the system boundaries of a specific tourism product alone, tourism LCA must include all needed consumption products and services (such as soap and shampoo provided during hotel stays) as well as production capital (such as the production, operation, maintenance and refurbishment of furniture and buildings) [35]. LCA-based calculations from research on greenhouse gas emissions resulting from the construction of hotels indicate that when assessing the tourism lifecycle of accommodation services, it is necessary to consider the environmental impact related to hotel construction. The environmental impact of hotel construction is not only reflected in terms of ecological designing objectives, but also in other building technologies, such as wooden structure technology and concrete structure technology [36]. Although LCA is aimed at studying all stages of tourism products or services, due to the complexity of the tourism system and the difficulty of obtaining detailed data, there are some limitations in the use of LCA. When using LCA and LCEA (life cycle energy analysis) to conduct environmental assessments for hotels, some studies have eliminated the environmental effects of hotel construction and hotel equipment [9]. Furthermore, some studies estimate that $15 \%$ of energy consumption and greenhouse gas emissions from hotel operations are from indirect emissions resulting from hotel construction. For example, a case study of two hotels in the city of Poole, in Dorset, UK, used this ratio to calculate the implicit emissions of building per guest per night, which were found to be $1.1 \mathrm{~kg} \mathrm{CO}_{2}$-eq and $0.7 \mathrm{~kg} \mathrm{CO}_{2}$-eq. The overall hotel emissions were estimated at $11.65 \mathrm{~kg} \mathrm{CO}_{2}$-eq, and $8.25 \mathrm{~kg} \mathrm{CO}_{2}$-eq [10]. This is about one-third to one-half of the emissions of the buildings and farmhouses type studied in this paper. This may be related to the variation in the levels of economic and technological development as well as accommodation types and scale across different countries and regions.

There are three primary limitations of this study. First, it is a bit unusual to include private household emissions as part of the tourism industry, for example, the emissions what the household members personally spend on food, residence, etc. This study uses the proportion of tourism income in household income to serve as the 'stripping coefficient' for tourism operators. It uses this coefficient to 'strip' tourism consumption from total household consumption data. In this way, this study distinguishes between tourism consumption data and overall household consumption data of tourism operators, and derives supply-side tourism consumption data. This method of attributing emissions as just the share of income from tourism is a rough a way to do this. Future studies can further explore other 'stripping' methods to improve data accuracy. Second, the operational lifetime of buildings should be more accurate. We referred to a paper to obtain the average life expectancy of rural housing construction in China (20 years) [23]. There are no records of structure lifetimes within the research area. It is important for the tourism industry in China to establish corresponding building indicators. Lastly, the limitation of our work is that we excluded the transportation element from tourism carbon emissions analysis. We primarily studied the carbon emissions of accommodation and services of the rural tourism operators and ignored the calculation of carbon emissions from tourism transportation. For future research, it is necessary to collect the data of tourist transportation in the surveyed area to analyze the carbon emissions from both supply-side and demand-side perspectives. For example, we should collect the energy consumption of transportation from the bus station and airport, also we should calculate the carbon emissions of the self-drive tourist. 


\section{Conclusions}

Overlooking the carbon emissions from construction and durable goods has led to the underestimation of carbon emissions by the tourism industry. Indirect carbon emissions are the primary source of emissions from accommodation and services in the surveyed area, accounting for $74.99 \%$ of the total. Emissions from construction and durable goods totalled $10.49 \mathrm{~kg} \mathrm{CO}_{2}$ per person per day, or $34.66 \%$ of the total lodgings and services emissions.

The development of the lodgings and services of tourism industry in the back-mountain area of Mount Qingcheng has been relatively low in terms of carbon emissions. However, the per-trip carbon emissions levels for the area are higher than the Chinese national average. For each additional 10,000 yuan in revenue, the accommodation and services of the rural tourism industry emit an additional $1412.08 \mathrm{~kg}$ of $\mathrm{CO}_{2}$; this is higher than the carbon emission values of the agriculture industry, but lower than those of the processing and manufacturing industries.

The process of carbon emissions resulting from accommodation and services in the surveyed area is primarily affected by tourist consumption demands and types of tourism operation. Different operation types make different contributions to the structure of carbon emissions. Among the different types of operators, store-type operators have the lowest carbon emissions levels, while the farmhouse-type operators have the lowest carbon emission intensity. This is the tourism operation type which exhibits the most obvious agglomeration effect. The consumption demands of tourists indirectly affect carbon emissions levels. From the above research, we can make three recommendations for reducing emissions in the tourism industry. First, changing the consumption behaviours of tourists and rural residents is the most direct way of achieving carbon emissions reductions in the tourism industry. We recommend calling on tourists to change their notions of consumption and consumer behaviour. For example, asking tourists to reduce their consumption of smoked or barbecued foods not only provides to their health, but also greatly reduces the use of energy sources such as firewood. We also recommend that catering service providers reduce carbon emissions in their procurement and preparation of foods, for example by avoiding vegetables grown in heated greenhouses and increasing use of local food products when procuring food, and by increasing the use of clean and renewable energy when preparing food. We also suggest that caterers find energy-efficient ways of preparing foods and reduce the preparation of energy-intensive foods (such as roast chicken and roast mutton). They may also increase the amount of vegetables on their menus, and separately manage food wastes and general wastes. Second, promoting everyday maintenance and management of these structures by rural residents and extending their uses will not only help reduce emissions from tourism construction, but also help preserve the original architecture of rural areas. The service life of constructions in China is generally lower than that in other countries. The service life of resident structures in other countries is up to 50 years, while that of public structures is between 50 and 70 years [37-44]. Finally, according to the different regulations and characteristics of carbon emissions in different operation types in the tourism industry, the industry's product layout structure should be adjusted and tourism management portfolios optimized in order to promote tourism emission reductions; for example, by combining the advantages of the farmhouse-and store-type operations with other operational types.

Acknowledgments: The author(s) disclosed receipt of the following financial support for the research, authorship, and/or publication of this article: the National Natural Science Foundation of China (Grant No. 41771163), the Ministry of Education of Humanities, Social Science Project (Grant No. 16YJC790060), Social Science Planning Annual Project of Sichuan, China (Grant No. SC15B046), Project of Chengdu Science and Technology Bureau (2015-RK00-00255-ZF) and Foundation of Sichuan Educational Committee (XHJJ-1514, JGYQ2015026).

Author Contributions: J.L. and C.L. conceived and designed the research; L.H., J.Z., L.W., and Y.L. collected the data; C.L. analyzed the data; all authors wrote and reviewed the paper.

Conflicts of Interest: The authors declare no conflict of interest. 


\section{References}

1. Scott, D.; Jones, B.; Konopek, J. Implications of climate and environmental change for nature-based tourism in the canadian rocky mountains: A case study of waterton lakes national park. Tour. Manag. 2007, 28, 570-579. [CrossRef]

2. Buzinde, C.N.; Manuel-Navarrete, D.; Kerstetter, D.; Redclift, M. Representations and adaptation to climate change. Ann. Tour. Res. 2010, 37, 581-603. [CrossRef]

3. United Nations Environment Programme (UNEP). Climate Change and Courism: Responding to Clobal Challenges; United Nations Environment Programme (UNEP): Nairobi, Kenya, 2008; Volume 12, pp. 168-181.

4. 2015 Bulletin of Tourism Statistics of the People's Republic of China. Available online: http://www.cnta.gov. cn/zwgk/lysj/201610/t20161018_786774.shtml (accessed on 10 April 2017).

5. Scott, D.; Amelung, B.; Becken, S.; Ceron, J.P.; Dubois, G.; Gossling, S.; Peeters, P.; Simpson, M.C. Climate Change and Tourism: Responding to Global Challenges; Advanced Summary; World Tourism Organization: Madrid, Spain, 2007.

6. Becken, S.; Patterson, M. Measuring national carbon dioxide emissions from tourism as a key step towards achieving sustainable tourism. J. Sustain. Tour. 2006, 14, 323-338. [CrossRef]

7. Dwyer, L.; Forsyth, P.; Spurr, R.; Hoque, S.; Scott, D.; Becken, S. Estimating the carbon footprint of australian tourism. J. Sustain. Tour. 2010, 18, 355-376. [CrossRef]

8. Zhou, M.R.; Tan, X.J. A review of foreign literatures on assigning responsibility for carbon emission embodied in international trade. J. Int. Trade 2012, 6, 104-113.

9. Camillis, C.D.; Raggi, A.; Petti, L. Tourism LCA: State-of-the-art and perspectives. Int. J. Life Cycle Assess. 2010, 15, 148-155. [CrossRef]

10. Filimonau, V.; Dickinson, J.; Robbins, D.; Huijbregts, M.A.J. Reviewing the carbon footprint analysis of hotels: Life cycle energy analysis (LCEA) as a holistic method for carbon impact appraisal of tourist accommodation. J. Clean. Prod. 2011, 19, 1917-1930. [CrossRef]

11. Michailidou, A.V.; Vlachokostas, C.; Moussiopoulos, N. A methodology to assess the overall environmental pressure attributed to tourism areas: A combined approach for typical all-sized hotels in Chalkidiki, Greece. Ecol. Indic. 2015, 50, 108-119. [CrossRef]

12. Pereira, R.P.T.; Ribeiro, G.M.; Filimonau, V. The carbon footprint appraisal of local visitor travel in Brazil: A case of the Rio de Janeiro-São Paulo itinerary. J. Clean. Prod. 2017, 141, 256-266. [CrossRef]

13. Kuo, N.-W.; Lin, C.-Y.; Chen, P.-H.; Chen, Y.-W. An inventory of the energy use and carbon dioxide emissions from island tourism based on a life cycle assessment approach. Environ. Prog. Sustain. Energy 2012, 31, 459-465. [CrossRef]

14. Bhochhibhoya, S.; Zanetti, M.; Pierobon, F.; Gatto, P.; Maskey, R.K.; Cavalli, R. The global warming potential of building materials: An application of life cycle analysis in Nepal. Mt. Res. Dev. 2017, 37, 47-55. [CrossRef]

15. Rogner, H.H.; Zhou, D.; Bradley, R.; Crabbé, P.; Edenhofer, O.; Hare, B. Mitigation; Contribution of Working Group III to the Fourth Assessment Report of the Intergovernmental Panel on Climate Change; Cambridge University Press: Cambridge, UK; New York, NY, USA, 2007.

16. Wang, Z. Study on Calcuation and Impact Factors of Carbon Emission from Residents's Consumption. Ph.D. Thesis, University of Science and Technology of China, Hefei, China, 2012.

17. Michailidou, A.V.; Vlachokostas, C.; Moussiopoulos, N.; Maleka, D. Life cycle thinking used for assessing the environmental impacts of tourism activity for a greek tourism destination. J. Clean. Prod. 2016, 111, 499-510. [CrossRef]

18. The Achievement of Dujiangyan-Qingcheng Mountain Area to Create Provincial Tourism Resort. Available online: http:/ / www.sc.xinhuanet.com/content/2011-11/23/content_24186708.html (accessed on 10 April 2017).

19. National Bureau of Statistics. China Energy Statistical Yearbook; China Statistics Press: Beijing, China, 2013.

20. 2014 Baseline Emissions Factors for Regional. Power Grids in China. Available online: http://www. tanpaifang.com/tanguwen/2016/0612/53638.html (accessed on 10 April 2017).

21. Wang, G.H. Analysis method on reducing emission of $\mathrm{SO}_{2}$ and $\mathrm{CO}_{2}$ by rural energy construction. Trans. CSAE 1999, 15, 169-172.

22. Qu, J.S.; Wang, L.; Qiu, J.L. Regional analysis of carbon dioxide emissions from house building materials in China. J. Lanzhou Univ. Nat. Sci. 2014, 50, 200-207. 
23. Han, J.; Xiang, W.N. Analysis of material stock accumulation in china's infrastructure and its regional disparity. Sustain. Sci. 2013, 8, 553-564. [CrossRef]

24. Wang, K.; Li, J.; Xi, J.C. Linking between carbon dioxide emissions and tourism economic growth in China. Tour. Trib. 2014, 29, 24-33.

25. Yuan, Y.J. Tourism in china: Indirect energy consumption and carbon emissions. Tour. Trib. 2013, $28,81-88$.

26. Shi, P.; Pu, W.U. A rough estimation of energy consumption and $\mathrm{CO}_{2}$ emissions in tourism sector of China. Acta Geogr. Sin. 2011, 66, 235-243.

27. Zhang, Z.; Liu, R. Carbon emissions in the construction sector based on input-output analyses. Qinghua Daxue Xuebao J. Tsinghua Univ. 2013, 53, 53-57.

28. Gössling, S.; Garrod, B.; Aall, C.; Hille, J.; Peeters, P. Food management in tourism: Reducing tourism's carbon 'foodprint'. Tour. Manag. 2011, 32, 534-543. [CrossRef]

29. Anton, A.; Montero, J.I.; Munoz, P. LCA and tomato production in Mediterranean greenhouses. Int. J. Agric. Resour. Gov. Ecol. 2005, 4, 102-112. [CrossRef]

30. Cederberg, C.; Wivstad, M.; Bergkvist, P.; Mattsson, B.; Ivarsson, K. Hållbart Växtskydd. Analys av Olika Strategier för Att Minska Riskerna Med Kemiska Växtskyddsmedel; Sveriges Lantbruksuniversitet: Uppsala, Sweden, 2005.

31. Kok, R.; Benders, R.M.J.; Moll, H.C. Energie-Intensiteiten van de Nederlandse Consumptieve Bestedingen anno 1996; IVEM, Centrum voor Energie en Milieukunde, Rijksuniversiteit Groningen: Groningen, The Netherlands, 2001.

32. Williams, A.G.; Audsley, E.; Jones, R.; Weller, R.; Bryson, R.; Philipps, L.; Whitmore, A.; Glendining, M.; Dailey, G. Determining the Environmental Burdens and Resource Use in the Production of Agricultural and Horticultural Commodities. 2006. Available online: http://randd.defra.gov.uk/Default.aspx?Module= More\&Location=None\&ProjectID=11442 (accessed on 20 September 2017).

33. Kuo, N.W.; Chen, P.H. Quantifying energy use, carbon dioxide emission, and other environmental loads from island tourism based on a life cycle assessment approach. J. Clean. Prod. 2009, 17, 1324-1330. [CrossRef]

34. Sun, Y.Y.; Pratt, S.; Yeoman, I.S.; Beeton, S. The economic, carbon emission, and water impacts of Chinese visitors to Taiwan: Eco-efficiency and impact evaluation. J. Travel Res. 2014, 53, 733-746. [CrossRef]

35. Camillis, C.D.; Peeters, P.; Petti, L.; Raggi, A. Tourism Life Cycle Assessment (LCA): Proposal of a New Methodological Framework for Sustainable Consumption and Production; InTech: Rijeka, Croatia, 2012.

36. Sesartic, A.; Stucki, M. How Climate Efficient Is Tourism in Switzerland? An Assessment of Tourism's Carbon Dioxide Emissions in Relation to Its Added Value; ETH: Zürich, Switzerland, 2007.

37. Lin, B.R.; Liu, N.X.; Peng, B.; Zhu, Y.X. International Comparative Study on Building Life-cycle Energy Consumption and $\mathrm{CO}_{2}$ Emission. Build. Sci. 2013, 29, 22-27.

38. Verbeeck, G.; Hens, H. Life cycle inventory of buildings: A contribution analysis. Build. Environ. 2010, 45, 964-967. [CrossRef]

39. Rosselló-Batle, B.; Moià, A.; Cladera, A.; Martínez, V. Energy use, $\mathrm{CO}_{2}$ emissions and waste throughout the life cycle of a sample of hotels in the balearic islands. Energy Build. 2010, 42, 547-558.

40. Ortiz-Rodríguez, O.; Castells, F.; Sonnemann, G. Life cycle assessment of two dwellings: One in Spain, a developed country, and one in Colombia, a country under development. Sci. Total Environ. 2010, 408, 2435-2443. [CrossRef] [PubMed]

41. Gustavsson, L.; Joelsson, A. Life cycle primary energy analysis of residential buildings. Energy Build. 2008, 42, 210-220. [CrossRef]

42. Gustavsson, L.; Joelsson, A.; Sathre, R. Life cycle primary energy use and carbon emission of an eight-storey wood-framed apartment building. Energy Build. 2010, 42, 230-242. [CrossRef]

43. Aste, N.; Adhikari, R.S.; Buzzetti, M. Beyond the EPBD: The low energy residential settlement Borgo Solare. Appl. Energy 2010, 87, 629-642. [CrossRef]

44. Blengini, G.A.; Carlo, T.D. The changing role of life cycle phases, subsystems and materials in the LCA of low energy buildings. Energy Build. 2010, 42, 869-880. [CrossRef]

(C) 2017 by the authors. Licensee MDPI, Basel, Switzerland. This article is an open access article distributed under the terms and conditions of the Creative Commons Attribution (CC BY) license (http:/ / creativecommons.org/licenses/by/4.0/). 